$\xi=$ 国

\title{
A Comparative Study of Destination Selection Attributes among Island Tourists
}

\author{
Fathilah Ismail ${ }^{1}$, Ahmad Puad Mat Som ${ }^{2 *}$, N Alia Fahada W Ab Rahman¹, Roseliza Mat Alipiah ${ }^{3}$ \\ ${ }^{1}$ School of Maritime Business \& Management, Universiti Malaysia Terengganu, 21300 Kuala Nerus, Terengganu, Malaysia \\ ${ }^{2}$ Faculty of Applied Social Sciences, Universiti Sultan Zainal Abidin, Gong Badak Campus, 21300 Kuala Nerus, Terengganu, Malaysia \\ ${ }^{3}$ School of Social Economics and Development, Universiti Malaysia Terengganu, 21300 Kuala Nerus, Terengganu, Malaysia \\ *Corresponding author E-mail: puadms@unisza.edu.my
}

\begin{abstract}
The objective of this research is to examine differences in the choice of destination attributes, from the perspective of cross-cultural visitors and local islanders at two world-class islands in Malaysia. Using a close-ended questionnaire and random convenience sampling method, data collection has been carried out at two most visited islands in Terengganu; Redang and Perhentian. A total of 391 respondents (tourists and local hosts) was involved in this study. The outcomes of this research have demonstrated that local hosts and island travelers responded to destination selection attributes differently. The hosts were concerned with the environment and island activities, while tourist groups emphasized on the availability of services and facilities on the islands. This study also highlights that Malay and western tourist have a significant different perception with regard to destination selection attributes. Western tourist are also seeking a chance to be part of the island community and take part in their daily lifestyle. This research provides information on destination selection attributes and highlights the importance of understanding about cultural differences among tourists and local hosts in delivering satisfactory services for the survival of island tourism over the long term.
\end{abstract}

Keywords: Destination Attributes; Island Settings; Cross-Cultural.

\section{Introduction}

Malaysia has built up a reputation as one of the world's most wellknown destinations for foreign tourists. The development of tourism industry in Malaysia has started since 1960s. Since then the industry has grown rapidly and contributed vastly to the Malaysian economy. Although Malaysia has experienced a rapid development in tourism, over the decade Malaysia only managed to attract a short haul market particularly from ASEAN countries [1]. The reliance of Malaysian tourism on a single source might jeopardize the Malaysian economy in the long term.

In spite of this problem, Malaysia is blessed with abundant natural resources including attractive small islands. As such, one of the major comparative advantages of Malaysia is to promote island based tourism.

Island destinations appear to be more appealing to long-haul markets such as the United States of America, United Kingdom, Europe, as well as Australia. However, these markets tend to have significant cultural differences from the local host communities. Therefore, issue of cross-cultural differences become important in understanding and avoiding conflicts between both incoming tourists and island communities. Knowledge of cultural dissimilarities between local host and island tourists at a particular destination could be used to provide satisfactory services for incoming tourists and potentially promote repeat visitation in the long term. As such, an understanding about cross-cultural issues between local hosts and tourists are important for the purpose of developing effective marketing strategies and formulate market segmentations, as well as to determine the ability of a particular destination to compete successfully worldwide [2]. Additionally, knowledge about the cross-cultural background of both host communities and island tourists is considered as a significant factor that could encourage travelers to visit a foreign land [3].

Island tourism relies heavily on their pristine beaches, flora and fauna diversity, as well as colorful coral reefs and underwater species [4]. A study at Sipadan Island, Malaysia demonstrates that marine life and corals of the island are the main factors of attraction to the tourists [5]. Similar attraction also tends to draw a large number of visitors to the Lakshaweep islands [6]. Nowadays, island tourism has become a phenomenon around the globe. As such, the competition among destinations become stiffer. As a result, small islands worldwide are struggling in marketing their destinations and retaining tourists on their islands.

One of the key instruments for effective destination marketing is the knowledge about customers' need. The main reason for commencing a research related to tourist need and satisfaction is the profit that could be gained from visitor satisfaction. There are three benefits that could be derived from a satisfied tourists; reduced customer price elasticity, positive word-of-mouth publicity and repeat visitation and [7].

Tourist satisfaction could be derived by comparing tourists' expectation with the actual service delivered to them [8]. Tourist satisfaction is defined as a post-purchase evaluation about particular products and services [9]. Knowledge about of visitors' satisfaction is essential when evaluating the quality of products and services offered by certain destinations [10]. Tourists' satisfaction will be affected by the availability of services. Therefore, in order to compete successfully in the marketplace, all businesses are trying hard to provide high quality services to their customers [11]. 
Failure to identify the importance variables that might influence customers' choice may resulted in the negative word-of-mouth [12]. Thus, information about the importance of destination attributes relates to tourist satisfaction and is crucial for destination marketers and managers if they want to promote and position a certain destination in the marketplace.

While there are abundant of studies have been undertaken pertaining destination attributes and visitor satisfaction [7-16], inadequate studies have been undertaken related to island tourism especially in the East Coast of Malaysia. With reference to the increase demand for island tourism in Malaysia and worldwide, it is crucial to examine what are the important factors that will persuade tourists in choosing their holiday destinations and increase their satisfaction. As tourism is now global and involves tourists from different cultural backgrounds, it is also crucial to examine this issue from a cross-cultural context. Therefore, the objective of this research is to explore the perceptions of multi-cultural island visitors and local host toward destination attributes.

\section{Methodology}

A self-administered, close-ended questionnaire was used to survey 391 sample at Perhentian and Redang Islands. The questionnaire has 3 major sections; host and tourist profile, tourist travel pattern and destination attributes. All the 24 attributes used in this study are derived from the previous studies [17-18]. Sample groups consist of local hosts and island tourists, namely European and Malay travelers. Principal Component Analysis (PCA) was adopted to condense the links among the observed variables and segregate the set of factors that most influenced tourists in the selection of travel destination. The Principal Component Analysis is a method to delineate the underlying dimension of destination attributes [19].

\section{Discussion}

This section presents study findings based on three contexts: hos and tourist profiles, tourist travel patterns and Principal Component Analysis (PCA) outputs. With regard to the host profile at Perhentian and Redang Islands, in total 107 respondents were surveyed. All the participating respondents are Malaysians. In term of gender, more than half of the respondents are men, aged between 21-40 years. More than $80 \%$ of the hosts at both islands are working in tourism-based industry.

There are two groups of tourists chosen for this study namely Malay and European tourists. Tourists to these islands dominated by young male travelers with the majority of the European travelers are from Italy, Denmark, France and Germany.

The visit characteristics of island tourists are categorized into four sections; length of stay, previous visitation, purpose of travel and type of tour. On average, Malay tourists only stay on both islands for 3 nights while European tourists stay for 6 nights. Most of European travelers visited these two islands for the first time as compared to the domestic tourists. As both islands are well-known with its natural beauty and exotic surroundings, both sample groups visit these island for the purpose of unwinding and relaxing from their hectic and stressful working lives. With regard to type of tour, the majority of European tourists are independent travelers while domestic tourists are on a package tour.

Table 1 below demonstrates the PCA results for the all three sample groups involved in this study; local hosts, European and Malay and tourists. The finding of the PCA for the local host group has resulted in six factor groupings. These six groupings are accounted for $66 \%$ of the variance. The PCA for the Malay sample extracted four components with total explained variance of $62 \%$. On the other hand, the PCA for the European tourists has extracted five components and accounted for $58 \%$ of the variance. As de- picted by Table 1, there are significant differences with regard to the choice of destination attributes across all selected sample groups.

The important destination attributes for the local hosts are correlated to the environment and activity. The majority of island tourists travelled to island destinations with the intention to take part in various water-based activities and appreciate the beauty scenery at island destinations. Thus, being local tourism operators, hosts remark that it is crucial to ensure tourists' safety on their island and keep the clean environment while offering a variety of activities to island tourists. The other important issue highlighted by the local hosts is related to destination image as a strong destination image could persuade tourists coming to their shores. Additionally, the local hosts also emphasize on the provision of high quality facilities on their islands such as quality accommodation, transportation services and a variety of eateries for domestic and international tourists. The availability of electricity around the clock and clean water also crucial to ensure utmost satisfaction of the island tourists. Currently, only a limited number of accommodation owners provide electricity on 24-hours basis while some accommodations facing a water supply problem.

Being guests, the Malay tourists appeared to place a great concern on island environment and facilities availability at island destinations. Therefore, the Malay visitors will take into consideration four important operating sectors in tourism; accommodation, transportation and food and beverage, as well as attractions before selecting their holiday destination. Sharing the similar view with the local hosts, the Malay travelers also point out the issue of their safety during vacation. The second most important destination attributes to the Malay tourists is services availability related banking and credit card. The other issue highlighted by this sample group is value for money. However, the Malay tourists have less focus on the availability of water-based activities at island destinations.

Table 1: The PCA Results

\begin{tabular}{c|l|c}
\hline \multicolumn{2}{c}{ Sample } & \multicolumn{1}{c}{ Perhentian and Redang Island } \\
\hline Group & \multicolumn{1}{c}{ Factor } & $\begin{array}{c}\text { \% of Variance } \\
\text { Explained }\end{array}$ \\
\hline Host & 1. Environment & 13.8 \\
& 2. Activities & 12.6 \\
& 3. Facilities & 12.4 \\
& 4. Other facilities & 11.4 \\
& 5. Money & 9.2 \\
& 6. Service availability & 7.1 \\
Malay & 1. Environment and facilities & 23.1 \\
& 2. Money and service availability & 18.0 \\
& 3. Activities & 10.5 \\
& 4. Other facilities & 10.1 \\
European & 1. Service availability & 14.9 \\
& 2. Money & 12.5 \\
& 3. Environment and facilities & 11.5 \\
& 4. Other facilities & 10.1 \\
& 5. Activities & 8.6 \\
\hline
\end{tabular}

With reference to the European travelers, they tend to have a slightly different view as compared to the other two sample groups, whereby their focus has been directed to the destination attributes related to the availability of services at island settings. Thus, the important factors for them in choosing a vacation destination are including the internet and communication services. Banking facilities and credit card service also played an important role to them. The travel characteristics of European travelers are quite different when compared with the local Malay tourists. This group of tourists usually travelled on a long period basis, sometimes up to a few months and prefer to travel as independent travelers. As such, the internet and communication facilities are crucial for them to get connected to beloved their family and friends. Additionally, being independent tourists, all expenses, particularly for the transportation and accommodation need to be paid when they arrived at the destinations. 
Similar to the Malay tourists, the European tourists are less concerned with activities. Thus, it could be concluded that the European tourists travel to Malaysian islands with the intention to enjoy our sun, sand and beach. Therefore, instead of focusing heavily on water-based activities, they tend to spend their time for relaxing and sun bathing. However, one of the activities appears to be exciting to European tourists is the opportunity to mingle around with the local islanders.

\section{Conclusion}

This research has indicated that over the decade, these two worldclass islands; Perhentian and Redang have a success story in attracting foreign travelers to their shores. However, their success story only limited to the two traditional markets such as the European and English speaking visitors. Therefore, in order to ensure the sustainability of island-based tourism and to stimulate higher growth rate of tourism receipts, marketing approaches need to be modified. For instance, efforts to promote the island destinations need to be extended to other markets as well. The new marketing efforts could focus on attracting Australians and New Zealanders to the Malaysian shores as visitors from these two countries have long been fascinated island destinations in our neighbouring countries; Indonesia and Thailand. New markets could also be explored, such as tourists from China and India. Additionally, this research also reveals that the European travelers are generally a risk-taker. Thus, one marketing strategy that could be adopted is to offer multi-island destination packages rather than a single island destination to maximize their touristic experiences. In Terengganu, there are a number of other island destinations such as Tenggol, Lang Tengah and Kapas, apart from Perhentian or Redang. Multidestinations travel is possible since these islands are located nearby to each other and could possibly extend visitors' average length of stay.

Infrastructure, which is important in sustaining tourism, has been emphasized by all tourist groups in selecting travel destinations. One important aspect that needs to be improved on by the government together with the industry players is the infrastructure and basic amenities at the tourist destinations, particularly transportation services and accommodation. For example, more budget accommodations are needed because most of the foreign island tourists in Malaysia are non-packaged visitors who usually have limited budgets. Island eateries operators should also offer a diverse type of food to meet tourists demand from around the globe.

The issue of solid waste management, i.e. waste and rubbish disposals, which will eventually harm the fragile eco-system is another significant outcome derived from this research. Naturebased tourism, which is popular among Western tourists, should seriously consider the issue of environmental preservation in the planning. This includes educating the local tourism operators, as well as other islanders on how to manage litter following international practices. Last but not least, tourists also need to be educated and reminded so that they will not throw any rubbish into the water as the rubbish will harmed and destroyed the beautiful and colorful coral reefs. This fragile environment of small islands should be adequately preserved to ensure the survival of island tourism. All parties, including government agencies, industry players, as well as island tourists should actively participate in the conservation of the environment, which may include heavy penalties to penalize any activities that could degrade the natural assets in these islands.

\section{Acknowledgement}

The authors would like to thank the Research Management, Innovation and Commercialization Centre, Universiti Sultan Zainal
Abidin, Terengganu, Malaysia for providing the financial aid to support the publication of this article.

\section{References}

[1] Tourism Malaysia (2018). Tourist arrivals and receipts to Malaysia. https://www.tourism.gov.my.

[2] Reisinger, Y., \& Turner, L. W. (1997). Cross-cultural differences in tourism: Indonesian tourists in Australia. Tourism Management, 18(3), 139-147.

[3] Reisinger, Y., \& Turner, L. W. (1998). Cultural differences between Mandarin-speaking tourists and Australian hosts and their impact on cross-cultural tourist-host interaction. Journal of Business Research, 42, 175-187.

[4] Fotiou, S., Buhalis, D., \& Vereczi, G. (2002). Sustainable development of ecotourism in small islands developing states (SIDS) and other small islands. Tourism and Hospitality Research, 4(1), 79-88.

[5] Musa, G. (2003). Sipadan: An over-exploited scuba diving paradise? An analysis of tourism impact, diver satisfaction and management priorities. In G. Brian \& W. Julie (Eds.), Marine Ecotourism: Issues and Experiences. Bristol: Channel View Publications, pp. 122-136.

[6] Kokkranikal, J., McLellan, R., \& Baum, T. (2003). Island tourism and sustainability: A case study of the Lakeshadweeps islands. Journal of Sustainable Tourism, 11(5), 426-447.

[7] Fornell, C. (1992). A national customer satisfaction barometer: The Swedish experience. Journal of Marketing, 56, 6-21.

[8] Barsky, J. (1992). Customer satisfaction in the hotel industry: Meaning and measurement. Hospitality Research Journal, 16(1), 308-315.

[9] Gundersen, M. G., Heide, M., \& Olson, U. H. (1996). Hotel guests' satisfaction among business travelers. Cornel Hotel and Restaurant Administration Quarterly, 37(2), 72-81.

[10] Schofield, P. (2000). Evaluating Castlefield urban park from the consumer perspective: Destination attribute importance, visitor perception and satisfaction. Tourism Analysis, 5(2-4), 183-189.

[11] Berry, L. L., \& Parasuraman, A. (1991). Marketing services: Competing through quality. Free Press.

[12] Chon, K. S., Christianson, D. J., \& Lee, C. L. (1995). Modeling tourist satisfaction: Japanese tourists' evaluation of hotel stay experience in Taiwan. Australian Journal of Hospitality Management, 2(1), 1-6.

[13] Kim, J. H. (2014). The antecedents of memorable tourism experiences: The development of a scale to measure the destination attributes associated with memorable experiences. Tourism management, 44, 34-45.

[14] Chi, C. G., \& Qu, H. (2008), Examining the structural relationships of destination image, tourist satisfaction and destination loyalty: An integrated approach. Tourism Management, 29, 624-636.

[15] Kim, K., Hallab, Z., \& Kim, J. N. (2012), The moderating effect of travel experience in a destination on the relationship between the destination image and the intention to revisit, Journal of Hospitality Marketing and Management, 21, 486-505.

[16] Crouch, G. I. (2011). Destination competitiveness: An analysis of determinant attributes. Journal of Travel Research, 50(27), 27-45.

[17] Qu, H., \& Li, I. (1997). The characteristics and satisfaction of mainland Chinese visitors to Hong Kong. Journal of Travel Research, 35(4), 37-41.

[18] Turner, L., \& Reisinger, Y. (1999). Importance and expectations of destinations attributes for Japanese tourists to Hawaii and Gold Coast compared. Asia Pacific Journal of Tourism Research, 4(2), 118.

[19] Tabachnick, B. G., \& Fidell, L. S. (2007). Using multivariate statistics. Pearson Education. 